\title{
Salas de recurso no Estado do Paraná: interfaces com a inclusão
}

\author{
Maria Cristina MARQUEZINE ${ }^{1}$
}

MORI, N. N . R.; GOULA RT, A. M. P. L. Educação einclusão: Estudo sobreas Salas de recurso no Estado do Paraná. Maringá: EDUEM, 2010.

Estelivro éo resultado do projeto E du cação e Inclusão no Paraná: as sal as de recurso, que foi financiado pela Fundação Araucária e coordenado pelas professoras Nerli Nonato Ribeiro Mori e Áurea Maria Paes Leme Goulart. Os textos publicados traçam um panorama muito interessante de uma realidade regional brasileira, a realidade do Estado do Paraná e da região de Maringá.

Os capítulos foram resultados de pesquisas desenvolvidas pelos professores ealunos do Programa dePós-Graduação em Educação daUniversidade Estadual de Maringá sobreos serviços deA tendimento Educacional Especializado (AEE), utilizados por alunos com necessidades educacionais especiais incluídos nas redes regulares de ensino.

Os organizadores da obra são profissionais reconhecidos pela competência e pela atuação na perspectiva histórico-cultural. Portanto, o livro se mantém coerentemente com os ditames dessa abordagem teórica.

O primeiro capítulo vem apresentar a legislação Federal, Estadual edo Município de Maringá no que tange ao atendimento de al unos com necessidades educacionais especiais. Trouxe informações interessantes e pouco divulgadas sobre a repercussão da legisl ação federal em instância Estadual e Municipal.

O segundo capítulo tratou da integração entre os alunos de classe especial esal a derecursos. N ele, pode-se encontrar uma boa discussão quemostra o atendimento educacional especializado como o caminho para a efetivação da inclusão.

O terceiro capítulo versou sobre a elaboração de conceitos científicos nos serviços de apoio a aprendizagem, o que tira da escola aquele aspecto amadorístico de algumas falas inclusivistas.

\footnotetext{
${ }_{1}^{1}$ Professor A djunto - Departamento de Educação - Centro de Educação, Comunicação e Artes - Universidade Estadual de Londrina - Londrina - PR - crisedes@uel.br 
O quarto capítulo abordou as questões da ação docente no ensino de conceitos matemáticos, tema visto como pouco frequente na literatura de área.

O quinto capítulo apresenta uma abordagem bastante feliz sobre o brincar no intervalo escolar dos alunos com necessidades educacionais especiais, incorporando o recreio como outro espaço de aprendizagem na escola.

Do sexto ao décimo capítulo, o leitor vai encontrar trabal hos depesquisa científica sobre as práticas pedagógicas em salas de recurso.

O sexto capítulo veio mostrar como é a prática pedagógica em sala de recurso de $5^{a}$ a $8^{a}$ série, de acordo com a abordagem inclusiva.

O sétimo capítulo trouxe a pesquisa sobre aprendizagem de leitura de alunos com dificuldades escolares em al unos matriculados, também, em salas de recurso.

O oitavo capítulo veio mostrar, por meio de pesquisa, como se pode desenvolver a escrita em salas de recurso, sem substituir ou repetir a prática desenvolvida nas salas regulares.

O nono capítulo trata da mediação pedagógica em sala de recursos e o último ou décimo capítulo que mostra um estudo comparativo entre alunos da sala regular e alunos da sala de recurso.

Baseado no fato de que em nosso país, as políticas públicas estão transformando o A tendimento Educacional Especializado em uma única modalidade de atendimento ao aluno com necessidades educacionais especiais, seria de extrema importância olhar para os dados de pesquisa apresentados no livro para que não se tenha que percorrer, outra vez, os mesmos caminhos anteriormente trilhados em Educação Especial. 